\title{
Some digenetic trematodes of the olive ridley sea turtle, Lepidochelys olivacea (Testudines, Cheloniidae) in Costa Rica
}

\author{
M. SANTORO*, J. A. MORALES \\ Departamento de Patología, Escuela de Medicina Veterinaria, Universidad Nacional, PO Box 86, Heredia 3000, Costa \\ Rica, E-mail: marisant@libero.it
}

\begin{abstract}
Summary
Three species of digeneans including 1 Gorgoderidae (Plesiochorus cymbiformis) from the urinary bladder, 1 Plagiorchiidae (Enodiotrema megachondrus) from the duodenum, and 1 Pachypsolidae (Pachypsolus irroratus) from the stomach were recovered from 2 of 3 olive ridley turtles (Lepidochelys olivacea) found stranded along the Pacific coast of Costa Rica. All trematodes represent new locality records. Histopathological changes associated with eggs of cardiovascular flukes (Digenea, Spirorchiidae) were described from the lungs, spleen, and intestine of a single turtle.
\end{abstract}

Key Words: Lepidochelys olivacea; olive ridley turtle; digeneans; spirorchiid eggs; Costa Rica

\section{Introduction}

The olive ridley turtle (Lepidochelys olivacea Eschscholtz, 1829 ) is the smallest living sea turtle. It is an omnivorous and opportunistic feeder, highly migratory distributed in the tropical and subtropical Atlantic, Indian, and Pacific oceans (Pritchard \& Trebbau, 1984). Few data exist on the digeneans of olive ridley turtle. To our knowledge the only reports from the Western Hemisphere are from Mexico by Parra (1983) and Pérez-Ponce de León et al. (1996). Here we report for the first time digenetic trematodes of olive ridley turtles from Costa Rica (Central America). Histopathological changes associated with eggs of cardiovascular flukes (Digenea, Spirorchiidae) were also described from internal tissues of a single turtle.

\section{Materials and Methods}

In March, August and October 2004, 2 juvenile (1 male and 1 female) and 1 adult female olive ridley turtles were collected from the Pacific coast of Costa Rica. The 2 juveniles that were obtained from the Gulf of Nicoya $\left(9^{\circ} 34^{\prime}\right.$ $44^{\prime \prime} \mathrm{N}, 84^{\circ} 36^{\prime} 34^{\prime \prime} \mathrm{W}$ ) were found stranded, alive, and severely debilitated with lesions on their flippers which were consistent with lesions caused by fishing nets. The debilitated turtles were brought to the Parque Marino de Puntarenas where they died a few days later. The adult female was found dead on the beach of Ostional $\left(10^{\circ} 00^{\prime} 00^{\prime \prime} \mathrm{N}, 86^{\circ} 45^{\prime}\right.$ $50^{\prime \prime} \mathrm{W}$ ), on the Nicoya peninsula. Curved carapace length (CCL) was measured and the chelonians were necropsied following the methods of Wolke and George (1981). Principal organs including the heart, great vessels, lungs, oesophagus, stomach, intestine, spleen, liver, gall bladder, kidneys, urinary bladder, and oviduct of the 2 juvenile turtles were examined for parasites following the methods of Greiner et al. (1980). Only the stomach and urinary bladder of the adult female were available for parasite examination. Trematodes were fixed in AFA (alcohol-formalinacetic acid), stained with Mayer's acid carmine, and mounted in Canada balsam for identification. Measurements are reported in micrometers (except when indicated) with the mean and standard deviation followed by the range in parenthesis.

Samples for histopathological examination were also obtained from the 2 juvenile turtles and routinely processed. Whole mounts and histological sections were studied by light microscopy. Voucher specimens were deposited in the Harold W. Manter Laboratory of Parasitology (HWML), Nebraska State Museum, Lincoln, Nebraska, U.S.A.

For comparative purposes specimens were borrowed from the Colección Nacional de Helmintos, Instituto de Biología, Universidad Nacional Autónoma de México (CNHE):

\footnotetext{
Corresponding author
} 
Plesiochorus cymbiformis (Rudolphi, 1819) Looss, 1901 (CNHE 233 - 8), Enodiotrema megachondrus (Looss, 1899) Looss, 1901b (CNHE $250-10$ ), and Pachypsolus irroratus (Rudolphi, 1819) Looss, 1902 (CNHE 253 - 12).

\section{Results and Discussion}

Three species of digeneans including 31 Plesiochorus cymbiformis (Gorgoderidae) from the urinary bladder, 3 Enodiotrema megachondrus (Plagiorchiidae) from the duodenum, and 1 Pachypsolus irroratus (Pachypsolidae) from the stomach were found in 2 of 3 olive ridley turtles.

The juvenile male (CCL $53 \mathrm{~cm}$ ) was negative for adult parasites, but was the only one positive for spirorchiid eggs. Histologically, fusiform eggs were seen within the lungs, spleen and intestine, and were associated with granulomatous reactions. Lesions consisted of $1-5$ degenerate eggs surrounded by histiocytes, lymphocytes, and giant cells. Myointimal and perivascular proliferation of fibrous connective tissue bordered by giant cells and few lymphocytes were observed from the small peripheral vessels of lungs and spleen. Vasculitis was associated with the eggs trapped in the lumen of minute vessels. No adult cardiovascular flukes or gross pathological changes associated with parasites were observed by necroscopy.

Spirorchiids are cosmopolitan flukes. Adult trematodes inhabit the cardiovascular system, where they copulate and lay eggs. The eggs migrate to tissues, where they elicit a granulomatous response in multiple organs (Glazebrook et al., 1989; Aguirre et al., 1998; Gordon et al., 1998; Jacobson et al., 2006). To date the life cycle of the marine spirorchiids is unknown. Histophatological changes described here were consistent with the lesions reported previously in other sea turtle species (Glazebrook et al., 1989; Aguirre et al., 1998; Gordon et al., 1998).

All trematodes represent new locality records. Flukes here found are generalist in sea turtles and have been collected previously from olive ridley, hawksbill (Eretmochelys imbricata), loggerhead (Caretta caretta), and green (Chelonia mydas) sea turtles (see below).

\section{TREMATODA}

Family: Gorgoderidae Looss, 1901

1. Plesiochorus cymbiformis (Rudolphi, 1819) Looss, 1901 Host: Lepidochelys olivacea, gravid adult female (CCL 68 $\mathrm{cm})$.

Locality and collection date: Ostional National Wildlife Refuge $\left(10^{\circ} 00^{\prime} 00^{\prime \prime} \mathrm{N}, 86^{\circ} 45^{\prime} 50^{\prime \prime} \mathrm{W}\right)$, on the Nicoya peninsula, north Pacific coast of Costa Rica; on October 2, 2004. Site of infection: urinary bladder.

Prevalence and intensity of infection: 1 of 3 hosts infected $(33.3 \%)$ with 31 specimens.

Voucher specimens deposited: HWML 48249.

Remarks: Thirty-one specimens found in the urinary bladder of the adult female concurred with the description of $P$. cymbiformis as given by Looss (1901b), Caballero y C. (1954), and Blair and Limpus (1982). P. cymbiformis is the only member of the genus. $P$. cymbiformis has a world- wide distribution. It has been reported from loggerheads in Australia, Egypt, Florida (U.S.A.), Greece, Italy, and New Guinea (Sonsino, 1893; Stossich, 1895, 1897; Braun, 1899; Looss, 1901a,b, 1902; Pratt, 1914; Cary, 1930; Pigulevsky, 1953; Sey, 1977; Blair \& Limpus, 1982; Manfredi et al., 1996), from green turtles in Egypt, Italy, Pacific coast of Panama, and south India (Rudolphi, 1819; Looss 1901a,b, 1902; Caballero y C., 1954; Chattopadhyaya, 1970), from hawksbills in south India (Chattopadhyaya, 1970) and Puerto Rico (Fischthal \& Acholonu, 1976), and from olive ridleys in Japan (Oguro, 1942) and Pacific coast of Mexico (Parra, 1983). Specific P. cymbiformis variations reported by most authors were discussed by Blair and Limpus (1982). Principal variations occurred for size and body shape, and testis and vitellaria shape and position. Smallest and largest specimens were $2.5 \mathrm{~mm}$ (Caballero y C., 1954) and $12 \mathrm{~mm}$ (Looss, 1901b), respectively. Our specimens were larger than largest fluke by Looss (1901b); the testes were dentritic in shape and overlapped the caeca reaching the lateral margin of body; vitelline glands were inter and extracaecal.

Measurements: $(\mathrm{N}=10)$ Body $14 \pm 1.0(12.8-15.7) \mathrm{mm}$ by $5.1 \pm 0.2(4.5-5.4) \mathrm{mm}$; oral sucker $960 \pm 86.6(840-$ $1,071)$ by $1,242 \pm 58.6(1,140-1,323)$; ventral sucker $1,720 \pm 129.6(1,512-1,890)$ by $1,739 \pm 119.5(1,575-$ $1,890)$; oesophagus $441 \pm 102.8(315-567)$; pharynx 326 $\pm 40.6(252-378)$ by $376 \pm 5.7(360-378)$; right testis $2,835.6 \pm 378.4(2,394-3,465)$ by $1,932 \pm 197.7(1,575-$ $2,142)$; left testis $2,905 \pm 311.0(2,400-3,402)$ by $1,956.6$ $\pm 171.7(1,638-2,205)$; ovary $536 \pm 79.6(441-630)$ by $570 \pm 95.1(378-693)$; right vitelline gland $796 \pm 169.5$ (567 - 945) by $509 \pm 115.8(315-630)$; left vitelline gland $731 \pm 111.2(567-882)$ by $571 \pm 50.5$ (504 - 567); Mehlis' gland $283 \pm 45.7(184-315)$ by $283 \pm 53.5(189-$ 378); eggs $(\mathrm{N}=10) 34 \pm 3.1(32-39)$ by $32 \pm 0.0$.

Family: Plagiorchiidae Lühe, 1901 (Ward, 1917)

2. Enodiotrema megachondrus (Looss, 1899) Looss, 1901b Host: Lepidochelys olivacea, juvenile female (CCL 35 $\mathrm{cm})$.

Locality and collection date: Gulf of Nicoya $\left(9^{\circ} 34^{\prime} 44^{\prime \prime} \mathrm{N}\right.$, $\left.84^{\circ} 36^{\prime} 34^{\prime \prime} \mathrm{W}\right)$, Puntarenas province, north Pacific of Costa Rica; on March 29, 2004.

Site of infection: duodenum.

Prevalence and intensity of infection: 1 of 2 hosts infected (50\%) with 3 specimens.

Voucher specimens deposited: HWML 48250.

Remarks: Three flukes from the duodenum of the juvenile female concurred with the description of E. megachondrus as given by Looss $(1899,1901 \mathrm{~b})$. According to Blair and Limpus (1982) the genus Enodiotrema includes 7 species: E. megachondrus, E. reductum Looss, 1901b, E. instar Looss, 1901b, E. acariaeum Looss, 1902, E. microvitellatus Chattopadhyaya, 1970, E. schikhobalovae Gupta \& Mehrotra 1976, E. carettae Blair \& Limpus 1982. E. megachondrus is the only species in the genus reported to date from an olive ridley. E. megachondrus has been detected in loggerheads from Egypt, France, Italy, and Spain (Braun, 
1901; Looss, 1901b, 1902; Euzet \& Combes, 1962; Manfredi et al., 1996; Aznar et al., 1998), in green turtles from Egypt (Looss, 1901b), in hawksbills from Cuba (Groschaft et al., 1977), and in olive ridleys from Mexico (PérezPonce de León et al., 1996).

Measurements: $(\mathrm{N}=3)$ Body $5.1 \pm 0.5(4.5-5.7) \mathrm{mm}$ by $1.1 \pm 0.0(1-1.2) \mathrm{mm}$; oral sucker $200 \pm 43.3(150-225)$ by $242 \pm 14.4(225-250)$; pharynx $83 \pm 14.4(75-100)$ by $108 \pm 28.8(75-125)$; ventral sucker $242 \pm 14.4$ (225$250)$ by $242 \pm 14.4(225-250)$; right testis $458 \pm 38.2$ $(425-500)$ by $450 \pm 25(425-475)$; left testis $508 \pm 14.4$ $(500-525)$ by $450 \pm 43.3(400-475)$; ovary $250 \pm 25$ $(225-275)$ by $267 \pm 14.4(250-275)$; vitelline follicles (from 8 to 12 in number on each side) $(\mathrm{N}=10) 127 \pm 14.2$ $(100-150)$ by $102 \pm 7.9(100-125)$; eggs $(\mathrm{N}=10) 36 \pm$ $3.4(32-39)$ by $14 \pm 2.1(13-19)$.

Family: Pachypsolidae Yamaguti, 1958

3. Pachypsolus irroratus (Rudolphi, 1819) Looss, 1902

Host: Lepidochelys olivacea, adult female (CCL $68 \mathrm{~cm}$ ).

Locality and collection date: Ostional National Wildlife Refuge $\left(10^{\circ} 00^{\prime} 00^{\prime \prime} \mathrm{N}, 86^{\circ} 45^{\prime} 50^{\prime \prime} \mathrm{W}\right)$, on the Nicoya peninsula, north Pacific coast of Costa Rica; on October 2, 2004.

Site of infection: stomach.

Prevalence and intensity of infection: 1 of 3 hosts infected $(33.3 \%)$ with 1 specimen.

Voucher specimen deposited: HWML 48251.

Remarks: A single specimen from the stomach of the adult female was identified as $P$. irroratus. Blair and Limpus (1982) recognized only 2 valid species in Pachypsolus: $P$. irroratus from the sea turtles and $P$. sclerops Travassos, 1922 from the crocodilians of South America. According to Blair and Limpus (1982), P. irroratus has been found in loggerhead, hawksbill, and green turtles in Australia, France, New Guinea, northwest Atlantic coast of Africa and Florida, Mexico, Panama, Puerto Rico, and Red Sea. Additionally $P$. irroratus has been reported in loggerheads from Italy (Manfredi et al., 1996) and Spain (Aznar et al., 1998) and in olive ridleys from Mexico (Pérez-Ponce de León et al., 1996).

Measurements: $(\mathrm{N}=1)$ Body $7.2 \mathrm{~mm}$ by $2.3 \mathrm{~mm}$; oral sucker 693 by 1,071 ; ventral sucker 945 by 819 ; pharynx 500 by 575 ; right testis 693 by 441 ; left testis 693 by 504; ovary 315 by 252 ; eggs $(\mathrm{N}=5) 71 \pm 0.0$ by $19 \pm 0.0$.

\section{Acknowledgments}

We are grateful to F. Bolaños, G. Chávez, J. Ramos Avilés, and the School of Biology of the Universidad de Costa Rica to permit the use of the Douglas Robinson Biological Station in Ostional and support the logistic assistance, and the Parque Marino de Puntarenas for providing us the juvenile turtles. The manuscript was improved by comments and advices from Mr. Garry Foster, University of Florida (USA). Research activities were conducted, under permission 091-2003/2004-OFAU from Ministry of Environment and Energy, and from the National System of Conservation
Areas of Costa Rica.

\section{References}

Aguirre, A. A., Spraker, T. R., Balazs, G. H., ZiMMERMAN, B. (1998): Spirorchidiasis and fibropapillomatosis in green turtles from the Hawaiian Island. J. Wildl. Dis., 34: $91-98$

AzNAR, F. G., BADILLO, F. J., RAGA, J. A. (1998): Gastrointestinal helminths of loggerhead turtles (Caretta caretta) from the western Mediterranean: constrains on community structure. J. Parasitol., 84: 474 - 479

Blair, D., LiMPUS, C. J. (1982): Some digeneans (Platyhelminthes) parasitic in the loggerhead turtle, Caretta caretta (L.), in Australia. Aust. J. Zool., 30: 653 - 680

BRAUN, M. (1899): Trematoden der Dahl'schen Sammlung aus Neu-Guinea nebst Bemerkungen über endoparasitisch trematoden der cheloniden. Zentralbl. Bakteriol. Parasitenkd. Abt. 1 Orig., 26: 627 - 633

Braun, M. (1901): Trematoden der chelonier. Mitt. Zool. Mus. Berl., 2: 5 - 58

CABAllero, y C. E. (1954): Helmintos de la República de Panamá. X. Algunos Tremátodos de Chelone mydas (L.) tortuga marina comestible del Océano Pacífico del norte. $1^{\mathrm{a}}$ parte. An. Inst. Biol. Univ. Nac. Autón. Méx., 8: $31-58$

CARY, L. R. (1930): Report on investigations at Tortugas. Studies on miracidia. Yearb. Carnegie Inst. Wash., 29: 325 $-329$

Chattopadhyaya, D. R. (1970): Studies on the trematode parasite of reptiles found in India (Digenetic flukes from the marine turtles from the Gulf of Mannar, South India). Helminthologia, 11: $63-65$

EuzeT, L., ComBes, C. (1962): Deux trématodes digénes de Thalassochelys caretta (L.). Bull. Soc. Zool. Fr., 87: 15 $-22$

Fischthal, J. H., Acholonu, A. D. (1976): Some digenetic trematodes from the Atlantic hawksbill turtle, Eretmochelys imbricata imbricata (L.) from Puerto Rico. Proc. Helm. Soc. Wash., 43: $174-185$

GlazeBrooK, J. S., CAMPBELl, R. S. F., BlaiR, D. (1989): Studies on cardiovascular fluke (Digenea: Spirorchiidae) infections in sea turtles from the Great Barrier Reef, Queensland, Australia. J. Comp. Pathol., 101: 231 - 250

Gordon, A. N., Kelly, W. R., CribB, T. H. (1998): Lesions caused by cardiovascular flukes (Digenea: Spirorchiidae) in stranded green turtles (Chelonia mydas). Vet. Pathol., 35: 21 - 30

Greiner, E. C., Forrester, J. J., JACOBSON, E. R. (1980): Helminths of mariculture-reared green turtles (Chelonia mydas) from Grand Cayman, British West Indies. Proc. Helm. Soc. Wash., 47: $142-144$

Groschaft, J., Otero, A. C., Tenora, F. (1977): Trematodes (Trematoda) from Cuban turtles Chelonia mydas mydas (L.) and Eretmochelys imbricata imbricata (L.) (Testudinata-Cheloniidae). Acta Univ. Agric. Fac. Agron., 25: $155-167$

Jacobson, E. R., Homer, B. L., Stacy, B. A., Greiner, E. C., Szabo, N. J., Chrisman, C. L., Origgi, F., Coberley, 
S., Foley, A. M., Landsberg, J. H., Flewelling, L., Ewing, R. Y., Moretti, R., Schaf, S., Rose, C., Mader, D. R., Harman, G. R., Manire, C. A., Mettee, N. S., Mizisin, A. P., Shelton, G. D. (2006): Neurological disease in wild loggerhead sea turtles Caretta caretta. Dis. Aquat. Org., 70: 139 - 54

Looss, A. (1899): Weitere beiträge zur kenntniss der trematoden fauna Aegyptens, zugleich versuch einer natürlichen gliederung des genus Distomum Retzius. Zool. Jahr. Syst., 12: $521-784$

Looss, A. (1901a): Natura doceri eine erklärung und begründung einiger grundsätze welche mich bei meinem "versuch einer natürlichen gliederung des genus Distomum Retzius" geleitet haben. Centralb. Bakt. Parasit. Abt. 1 Orig., 29: $191-210$

Looss, A. (1901b): Notizen zur helminthologie Egyptens. IV. Ueber trematoden aus seeschildkröten der Egyptischen küsten. Centralb. Bakt. Parasit. Abt. 1 Orig., 30: 555 - 569 Looss, A. (1902): Ueber neue und bekannte trematoden aus seeschildkröten. Nebst erörterungen zur systematik und nomenclatur. Zool. Jahr. Syst., 16: $411-894$

Manfredi, M. T., Piccolo, G., Meotti, C. (1996): Parasites of Italian sea turtle. II. Loggerhead turtles (Caretta caretta Linnaeus, 1758). Parassitologia, 40: 305 - 308

OGURO, Y. (1942): Short report of trematodes of chelonians. Zool. Mag., 54: 164

PARRA, R. L. (1983): Estudio de algunos monogéneos y tremátodos parásitos de reptiles de México. Tes. Grad., Universidad Nacional Autónoma de México
PÉrez-Ponce de LeÓn, G., García-Prieto, L., LeÓNRÉGAGNON, V. (1996): Gastrointestinal digenetic trematodes of olive ridley's turtle (Lepidochelys olivacea) from Oaxaca, Mexico. Taxonomy and infracommunity structure. Proc. Helm. Soc. Wash., 63: $76-82$

Pigulevsky, S. V. (1953): Family Gorgoderidae. In K. I. Skrjabin (Ed.): Trematodes of Animals and Men., Vol. 8. Akademii Nauk, Moscow, 253 - 615

PRATT, H. S. (1914): Trematodes of the loggerhead turtle (Caretta caretta) of the Gulf of Mexico. Arch. Parasitol., 16: $411-427$

Pritchard, P. C. H., TrebBau, P. (1984): The turtles of Venezuela. Contributions to Herpetology 2. Society for Study of Amphibians and Reptiles. Oxford, Ohio

RudOLPHI, C. A. (1819): Entozoorum synopsis cui acedunt mantissa duplex et indices locupletissimi. August Rücker, Berolini

SEY, O. (1977): Examination of helminth parasites of marine turtles caught along the Egyptian coast. Acta Zool. Acad. Sci. Hung., 23: $387-394$

Sonsino, P. (1893): Trematodi di rettili e anfibi della collezione del Museo di Pisa. Atti Soc. Toscana Sci. Nat. Pisa P. V. Mem., 8: $183-190$

Stossich, M. (1895): Notizie elmintologiche. Boll. Soc. Adriat. Sci. Nat., 16: $33-46$

Stossich, M. (1897): Note parassitologiche. Boll. Soc. Adriat. Sci. Nat., 18: 1 - 10

Wolke, R. E., GEORGE, A. (1981): Sea turtle necropsy manual. National Oceanic and Atmospheric Administration, Technical Memorandum, NMFS-SEFC-24, NOAA

ACCEPTED NOVEMBER 4, 2006 